\title{
Mantodea from Eastern Caribbean Islands
}

Nicolas Moulina*, François Meurgeyb \& Sylvain Hugel

aInstitut Systématique, Évolution, Biodiversité (ISYEB), Muséum national d’Histoire naturelle, UMR 7205, MNHN, CNRS, Sorbonne Université, EPHE, Université des Antilles, CP50, 45 rue Buffon, 75231 Paris Cedex 05, France; bDépartement d'entomologie, Muséum d'Histoire Naturelle, 12 rue Voltaire, 44000 Nantes, France; cINCI, UPR 3212 CNRS, Université de Strasbourg, 8 allée du Général- Rouvillois, 67000 Strasbourg, France

\section{Summary.}

Whereas Mantises of Trinidad and Tobago have been comprehensively studied, species occurring on more northern islands of Lesser Antilles are little known. The present work aims at updating the current knowledge on Mantises from Eastern Caribbean Islands by compiling data from both published and grey literature, museum specimens as well as specimens we and others collected during surveys conducted over the last decades. Thesprotiella insularis (Bonfils, 1967) is revealed to be widely distributed on islands harboring moist and wet forests from Martinique to Guadeloupe. Liturgusa dominica Svenson, 2014 occurs in humid and subhumid forests of Dominica and Marie-Galante. Gonatista reticulata (Thunberg, 1815) and Thesprotia caribea Rehn \& Hebard, 1938 appear restricted to the northernmost islands of the Northeast Lesser Antilles. Musonia surinama Saussure, 1869 is present in the grassland of St Martin and of Southern islands (Barbados, St. Vincent, and Grenada). Lobocneme lobipes (Redtenbacher, 1892) is only present in St. Vincent and Grenada. Epaphrodita undulata (Saussure, 1870) is re-established as synonym of Epaphrodita musarum (Palisot de Beauvois, 1805); this species was described from St. Lucia, but has not been recorded for over 150 years. Finally, a specimen of Bantiella trinitatis Giglio-Tos, 1915 was collected on Martinique in 1975, but this species was not collected again. Despite intensive searching, four nonendemic species once recorded on the archipelago have not been recorded again and might correspond to temporary settlements or to erroneous data. Acontista multicolor Saussure, 1870 does not appear to currently occur on Guadeloupe. Distribution, ecology and phenology of these species are discussed.

\section{Résumé.}

Les Mantes des îles de la Caraïbe orientale. Alors que les Mantes de Trinidad et Tobago ont été largement étudiées, les espèces présentes plus au nord et à l'est de l'archipel l'ont beaucoup moins été. L'objectif du présent article est d'actualiser les connaissances sur les mantes du nord-est des Petites Antilles, en nous appuyant sur les données publiées, celles présentes dans la littérature grise, les collections et les spécimens collectés durant les dernières décennies. Thesprotiella insularis (Bonfils, 1967) s’avère largement présent sur les îles arborant des forêts hygrophiles ou mésophiles de la Martinique à la Guadeloupe. Liturgusa dominica Svenson, 2014 est présent en Dominique et à Marie-Galante. Gonatista reticulata (Thunberg, 1815) et Thesprotia caribea Rehn \& Hebard, 1938 ont leurs populations restreintes aux îles les plus au nord des Petites Antilles. Musonia surinama Saussure, 1869 est présent dans les milieux herbacés de St. Martin et dans ceux des îles du sud (Barbades, St. Vincent et Grenade). Lobocneme lobipes (Redtenbacher, 1892) est restreint à St. Vincent et Grenade. La synonymie entre Epaphrodita undulata (Saussure, 1870) et Epaphrodita musarum (Palisot de Beauvois, 1805) est rétablie ; cette mante est endémique de St. Lucie, mais n’a plus été signalée depuis plus de 150 ans. Enfin, un spécimen de Bantiella trinitatis Giglio-Tos, 1915 a été collecté en Martinique en 1975 mais n’a plus été signalé depuis. Malgré des recherches intensives, quatre espèces non endémiques, rencontrées une seule fois dans l'Archipel, pourraient correspondre à des établissements temporaires ou à des données erronées. Acontista multicolor Saussure, 1870 ne semble pas se reproduire actuellement en Guadeloupe. La distribution, l’écologie et la phénologie de ces espèces sont discutées.

Keywords:

Lesser Antilles; Caribbean; Mantodea; Acontistidae; Liturgusidae; Thespidae; Epaphroditidae; Mantidae; geographical distribution; ecology

The Caribbean region is considered a threatened biodiversity hotspot because of its high levels of biotic diversity and endemism and widespread habitat destruction (Myers et al. 2000; Mittermeier et al. 2005; Wetterer et al. 2016). A better preservation of this unique biodiversity requires knowing the distribution of the species harbored by these islands. This has been addressed for various groups of insects such as beetles (Chalumeau \& Touroult 2005; Peck 2006; Ivie et al. 2008; Peck 2009; 2010, 2011, 2016; UICN Comité français, OFB, MNHN 2020), moths and butterflies (Martin Brown 1978; Miller \& Miller 2001; Davies \& Birmingham 2002; Fontenla 2003; Pierre \& Lalanne-Cassou 2014; Touroult et al. 2014a; Zagatti et al. 2021), and bees (Meurgey 2014, 2016; Meurgey \& Questel 2015; Meurgey \& Dumbardon-Martial 2016, 2019; UICN Comité français, OFB, MNHN 2020). Unfortunately, the current decline in biodiversity is accompanied by a growing list of species that are not identified (Touroult et al. 2020a). Knowledge on the Mantises of the Lesser Antilles is very uneven. Whereas species of Trinidad and Tobago at the South of the archipelago are comprehensively known by both historical and recent records (Bruner 1906; Rehn 1911; Giglio-Tos 1915, 1927; Beier 1935a; Beebe et al. 1952; Crane 1952; McEDK 1953; Quesnel 1967; Terra 1995; Agudelo et al. 2007; Greener et al. 2014; Greener \& Rutherford 2014), species occurring on more northern islands as well as their distribution are very little known.

Nine species are currently recorded from Northeastern Lesser Antilles: Gonatista reticulata (Thunberg, 1815); Musonia surinama (Saussure, 1869); Thesprotia caribea Rehn \& Hebard, 1938; Thesprotiella insularis (Bonfils, 1967); Liturgusa dominica Svenson, 2014; Acontista multicolor Saussure, 1870; Lobocneme lobipes (Redtenbacher, 1892); Bantiella trinitatis Giglio-Tos, 1915; and Epaphrodita musarum (Palisot de Beauvois, 1805).

Since these early accounts by Thunberg (1815), Brunner \& Redtenbacher (1892), Saussure (1870), Rehn \& Hebard (1938), Bonfils (1967), Mantises were scarcely reported on Northeastern Lesser Antilles in published accounts of scientific surveys (Miskimen \& Bond 1970; Bennet \& Alam 1985; Woodruff et al. 1998). 
Besides these scarce records on Mantises of Northeastern Lesser Antilles, many specimens were collected by various entomologists. For example, between 1954 and 1977, Robert Pinchon collected Mantises among other insects in Martinique. Pinchon's specimens in MNHN were later identified by Roger Roy but the records remained unpublished. More recently, many entomologists regularly collected Mantises in the area. The present work aims at updating the current knowledge on Mantises from Northeast Lesser Antilles by compiling data from both published and grey literature, museum specimens as well as specimens we and others collected during surveys conducted over the last decades.

\section{Material and methods}

The geographic scope of the present work ranges includes Lesser Antilles localized north to Trinidad and Tobago (Windward and Leeward islands). The distribution maps were made using QGIS software 3.8 Zanzibar. The administrative area is from http://www.diva-gis.org.

The taxonomy used is from Schwarz \& Roy (2019) and Rivera \& Svenson (2016, 2020).

In addition to the authors' ones the following collections were examined by NM: Mantodea collection in the Muséum national d'Histoire naturelle (Paris, France), the Pinchon insect collection (Fort-de-France, Martinique), the insect collection of INRAE Antilles-Guyane (Petit-Bourg, Guadeloupe).

The continuum of the flora is divided into general zones (Peck 2016): littoral, xerophile zone (dry forest and shrubby environment), mesophile zone (sub humid forest), and hygrophile zone (rain forest). These intergrade into each other with distance from the salt influence of the sea, if the habitat is on the windward (east) or leeward (west) side of the island, and with increasing rainfall and decreasing average temperature accompanying an increase in elevation above sea level. This work takes advantage of the huge contribution of the following entomologists who kindly transmitted their observations and/or who contributed to unpublished reports we examined:

Julien Chalifour, Cul-de-Sac, Saint-Martin; Mathieu Coulis, Fort-de-France, Martinique; Gwénael David, Lons-le-Saunier, France; Francis Deknuydt, Trois Ilets, Martinique; Régis Delannoye, La Trinité, Martinique; Thomas Dubreuil, Schoelcher, Martinique; Eddy Dumbardon-Martial, Fort-de-France, Martinique; Toni Jourdan, Baie-Mahault, Guadeloupe; Gilles Leblond, Sainte-Rose, Guadeloupe; Karl Questel, Saint Barthélemy; Daniel Romé, Le Vauclin, Martinique; Philippe Ravat, Anses d'Arlet, Martinique; Guillaume Viscardi, Le Carbet, Martinique. Many of these collectors are involved in very dynamic NGOs: Martinique Entomologie, Société Entomologique Antilles-Guyane (SEAG), Société d'histoire naturelle L'Herminier (SHNLH). These NGOs as well as NM produced reports we examined for the present work: (Touroult \& Poirier 2012, 2013, 2014b; Touroult et al. 2015, 2016, 2017, 2018, 2019; Jourdan \& Moulin 2020). These reports were produced for Direction de l'Environnement et de l'Aménagement du Littoral (DEAL Martinique or DEAL Guadeloupe).

Several data were recorded from the iNaturalist platform, which is one of the world's most popular online wildlife databases, helping participants (over 750,000 scientists and naturalists) to identify plant and animal species they observed. iNaturalist is a joint initiative by the California Academy of Sciences and the National Geographic Society (Moulin 2020).

During the field surveys by the authors, mantises were collected using the three main methods (manual collecting, light trapping and tree climbing) as listed in Brannoch et al. (2017).

\section{Abbreviations}

ABS, Archbold Biological Station, Dominica; ANSP, Academy of Natural Sciences of Philadelphia, Philadelphia, PA, USA; CDR, Collection Daniel Romé, Le Vauclin, Martinique; CEDM, Collection Eddy Dumbardon-Martial, Fort-de-France, Martinique; CFD, Collection Francis Deknuydt, Trois Ilets, Martinique; CFM, Collection François Meurgey, Nantes, France; CGV, Collection Guillaume Viscardi, Le Carbet, Martinique; CGD, Collection of Gwénael David, Lons-le-Saunier, France; CJC, Collection Julien Chalifour, Cul-de-Sac, St. Martin; CKQ, Collection Karl Questel, Saint Barthélemy; CM, Carnegie Museum of Natural History, Pittsburgh, PA, USA; CMC, Collection Mathieu Coulis, Fort-de-France, Martinique; CMJ, Collection M. Jegu, Guadeloupe; CPG, Collection Pierre \& Claudine Guezennec, Guadeloupe; CPR, Collection Philippe Ravat, Anses d'Arlet, Martinique; CRD, Collection Régis Delannoye, La Trinité, Martinique; CRPP, Collection R. P. Pinchon, Fort-de-France, Martinique; CRT, Collection Romain Tremblay, Guadeloupe; CSH, Collection Sylvain Hugel, Strasbourg, France; CTD, Collection Thomas Dubreuil, Schoelcher, Martinique; CTJ, Collection Toni Jourdan, BaieMahault, Guadeloupe; INRAE, Institut National de Recherche pour l'Agriculture, l'Alimentation et l'Environnement, PetitBourg, Guadeloupe; MNHN, Muséum national d'Histoire naturelle, Paris, France; RCNM, Research Collection of Nicolas Moulin, Montérolier, France; USNM, National Museum of Natural History, Smithsonian Institution, Washington, DC, USA.

\section{Results}

\section{Annotated list of species}

The species are presented according to the classification of families and sub-families of Schwarz \& Roy (2019) and Rivera \& Svenson (2020). For each species, the specimens are presented in the chronological order of their capture and/or observation.

\section{Family Thespidae}

Keys to genera are presented in recent work (Rivera \& Svenson 2020). Distribution data are reproduced here with updates of classification.

Bantiella trinitatis Giglio-Tos, 1915 (Figure 8a-d)

Bantiella trinitatis Giglio-Tos 1915, p. 186.

Distribution. Guyana, Trinidad and Tobago, Venezuela.

Material examined. Martinique. 1§̄, 'Martinique N.', 23.IV.1976, Carayon leg. (MNHN).

An adult male of $B$. trinitatis labelled as coming from Martinique is conserved in MNHN. This species is known from Trinidad and Tobago (Giglio-Tos 1915, 1927; Beebe et al. 1952; McEDK 1953; Marshall 1975; Terra 1995; Ehrmann 2002; Otte \& Spearman 2005; Agudelo et al. 2007; Greener \& Rutherford 2014; Patel et al. 2016; Rivera \& Svenson 2020; Otte et al. 2021; INaturalist 2021) and was not collected again in Martinique 
despite strong sampling efforts over the last decades (Bonfils 1967; 1969; Touroult \& Poirier 2012; Touroult et al. 2013, 2014b, 2015, 2016, 2017, 2018, 2019, 2020b; Jourdan \& Moulin 2020).

Musonia surinama (Saussure, 1869) (Figures 1, 2a, b, 8e, f)

Thespis surinama Saussure 1869, p. 70.

Distribution. Antigua (Pelican Island), Barbados, Colombia, Costa Rica, Ecuador, French Guyana, Grenada, Guyana, Nicaragua, Panama, St. Martin, St. Vincent, Surinam, Trinidad and Tobago, Venezuela.

Material examined. Grenada. 1ð, Grand Etang lake, St Andrew’s parish, 12.III.2009, Meurgey leg. (CFM). St. Martin. $2 \hat{\jmath}$, Port Caraibes Residense, Anse Marcel, attracted by habitation lights, XII.2012, 2014; $13 \hat{\jmath}$ (genitalia preparation NM0202), Park View, Cul-de-Sac, attracted by habitation lights, 30.X.2015, 2016, 2018, 2019, IX-XI.2020; 1 , Hope Estate, day, 21.XII.2020, Chalifour leg. (RCNM, CJC).

St. Vincent. $1 \partial^{\lambda}$, tall grass of a meadow, Mesopotomia valley, St Georges parish, 29.III.2012, Meurgey leg. (CFM); $1 \hat{\jmath}$, on Cyathea sp., La Soufrière, Charlotte’s parish, 13.IV.2012, Meurgey leg. (CFM); $1 \delta^{\lambda}$, on Banana tree, Troumaca, St Patrick's parish, 16.IV.2012, Meurgey leg. (CFM).

Other data. Antigua. 3 , Pelican Island, V.1914 (Caudell 1922).

Barbados. 1ð̄, 1 9 , no data for male and 'in May' for female; several nymphs, Hawkins Estate, Prof. Stoner

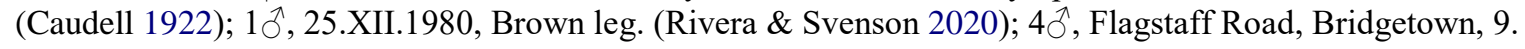
IV.2017, 12-14.IX.2017, Taylor leg. (INaturalist 2021).

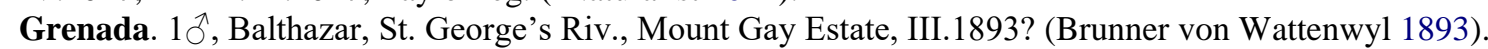
St. Vincent. Windward side, IX.1891? (Redtenbacher 1892).

M. surinama has been described after a male specimen from Suriname (Saussure 1869). In 1871, Saussure produced a more detailed description of this species. He indicated also that the specimen is conserved at the MNHN. However, this type is not cataloged in the entomological collections of the MNHN (https://science. mnhn.fr). Later, Ehrmann (2002) indicated that the type is conserved in the Geneva museum (MHNG). This location was later mentioned by Otte \& Spearman (2005). However, neither Roy \& Cuche (2008) nor Pfäuti \& Hollier (2012) listed this type as present in their inventory of type material in the Geneva collections. In their comprehensive work on Thespidae, Rivera \& Svenson (2020) examined a large number of collections and failed to locate the type. Therefore, at this stage, the type of Musonia surinama should be considered as lost. The holotype of Mionyx lineatus (Chopard, 1912) was later considered as synonym of M. surinama, and Mionyx fuscescens (Chopard, 1912) was confirmed as synonym of M. surinama (Rivera \& Svenson 2020). In the same work, examination of numerous specimens indicated that M. surinama was restricted to northern South America, Trinidad, St. Vincent and Barbados.

So, M. surinama appears to be restricted to northern South America, Trinidad, Grenada, St. Vincent and Barbados (Saussure 1869, 1871; Stål 1877; Redtenbacher 1892; Brunner von Wattenwyl 1893; Saussure \& Zehntner 1894; Kirby 1904; Bruner 1906; Chopard 1912; Hebard 1919, 1921, 1922, 1924, 1933; Caudell 1922; Giglio-Tos 1927; Beier 1935a; La Greca 1939; Terra 1995; Ehrmann 2002; Otte \& Spearman 2005; Agudelo et al. 2007; Patel et al. 2016; Roy 2019; Moulin \& Roy 2020; Rivera \& Svenson 2020; Otte et al. 2021). The absence of this species surprising (see discussion). The species appears well settled on these northern localities since it has been observed at various times and islands. We detected no morphological differences between specimens from St. Martin and the specimens from French Guiana and Panama.

Thesprotiella insularis (Bonfils, 1967) (Figures 3a, b, 4a, b, 9a-d)

Oligonyx insularis Bonfils 1967, p. 244.

Distribution. Dominica, Guadeloupe, Marie-Galante, Martinique.

Material examined. Guadeloupe. 13ð̋ (holotype, paratypes), 1ㅇ (allotype), Petit-Bourg, Duclos, between 1962 and 1965, Bonfils leg. (MNHN-INRAE); 10̄, Massif de la Soufrière, La Citerne, 19.I.1966, Bonfils leg.

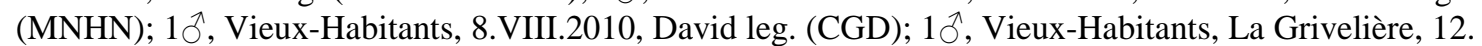
VIII.2010, Meurgey leg. (CFM); 1ठ̄, Capesterre-belle-eau, Marquisat, Routhiers, 16.II.2011, Meurgey leg. (CFM); 1 nymph, Trois-Rivières, 21.VIII.2013, Guezennec leg. (CPG); 1§̂, Sainte Rose, Route forestière de Duportail, 23.III.2015, Meurgey leg. (CFM); $1 \hat{\jmath}$, Deshaies, Piton de Sainte Rose, 14.V.2015, Meurgey leg. (CFM); $1 \hat{\jmath}$, Bouillante, crête de village, 22. V.2015, Meurgey leg. (CFM); $1 \delta^{\lambda}$, Capesterre, au niveau de l’observatoire, Grand Etang, 16.II.2016, Meurgey leg. (CFM); 1Ō, Saint-Claude, Trace Victor Hughes, Matouba, 13.VI.2016, Meurgey leg. (CFM); 1 , Gourbeyre, Chemin du Bassin Bleu, forêt, 13.XI.2016, Hugel leg. (CSH); 1 , , Pointe Noire, trace du Morne Léger, 23.XI.2016 Hugel leg. (CSH); 6 ${ }^{\lambda}$, Gourbeyre, le Houelmont, sentier découverte, 18 m Canopy, 15. VI.2017, Meurgey leg. (CFM); $8 \hat{\jmath}$, Trois-Rivières, Chutes du Carbet, parcelles Parc National de Guadeloupe, 25 m canopy, 20.VI.2017, Meurgey leg. (CFM); 1ㅇ, Deshaies, Morne Mazeau, Route forestière vers Borne Bois d’Inde, 24.VI.2017, Hugel leg. (CSH); 4 ${ }^{\lambda}$, Saint-Claude, Bains-Jaunes, 21 m canopy, 27. VI.2017, Meurgey leg. (CFM); 1ð̃, Petit-Bourg, Piolet, route de la Traversée, 12.III.2018, Meurgey leg. (CFM); 1옹 Saint-Claude, Saut d'eau de Matouba, 2.III.2019, Touroult leg. (RCNM); 1 nymph, PointeNoire, trace Contrebandiers, 3.III.2019, Touroult leg. (RCNM); $1 \hat{\delta}$, Goyave, Route forestière de Moreau, 19.III.2019, Guezennec leg. (CPG); $1 \partial^{\lambda}$, Saint-Claude, Ma Folie, 19. III.2019, Guezennec leg. (CPG); 1 , , SaintClaude, 19. IV.2019, Guezennec leg. (CPG); 1ㅇ, Sainte-Rose, Boucle de Sofaïa, 15.VI.2019, Coulis leg.

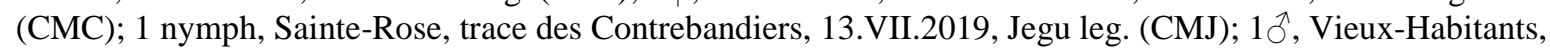


Refuge des 3 Crêtes, 2.V.2020, Jourdan leg. (CTJ); 1우, Bouillante, Duprat, D14, 25.V.2020, Tremblay leg. (CRT).

Marie-Galante. 19, Grand Bourg, Les Sources, VIII.2004, Hugel leg. (CSH); Grand Bourg, Les Sources, 2.VIII.2007, Hugel leg. (CSH); 1 §̃, 2ᄋ, 1 nymph, 1 ootheca, Grand Bourg, Coulée Ouliée haut, 8.VIII.2011, Hugel leg. (CSH); 1 , Capesterre de Marie-Galante, Les Balisiers, 6.VIII.2017, Hugel leg. (CSH); 1 , Capesterre de Marie-Galante, les Balisiers, hand catching, 5.VI.2019, Moulin leg. (RCNM); $1 \delta^{\jmath}$, Saint-Louis, Les Sources, LED trap, 6.VI.2019, Moulin leg. (RCNM); 1 nymph, Saint- Louis, Ravine Potens, hand catching, 6.VI.2019, Moulin leg. (RCNM).

Martinique. 1ð̄, Morne Rouge, Périnelle, 17.I.1954, Pinchon leg. (CRPP); 3ð̋, Gros Morne, Annexe, 27.

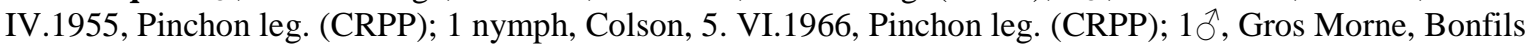
leg. 1969 (MNHN); 19, Trinité, 4.XI.1975, Pinchon leg. (CRPP); 1ð̃, Sainte-Marie, 2.XII.1975, Pinchon leg. (CRPP); $1 \hat{\jmath}$, La Médaille, Fort-de-France, 19.I.1977, Pinchon leg. (CRPP); $1 \hat{\jmath}$, Marigot, Morne Laroche, 30. III.2008, David leg. (CGD); 1§̂, Fonds Saint-Denis, Arborétum de l’Alma, 3.VIII.2008, Hugel leg. (CSH); $1 \hat{\jmath}$, Morne Vert Pré, Le Vert Pré, VI.2010, Delannoye leg. (CRD); 1 , Route forestière de Grand Fond, Fond SaintDenis, 20.IX.2010, Deknuydt leg. (CFD); 1 nymph, Piton du Carbet, 1.III.2011, Romé leg. (CDR); 1 , Route forestière de Grand Fond, Fond Saint-Denis, 12.IX.2011, Delannoye leg. (CRD); $1 \hat{\jmath}$, Morne Bellevue, Le Marigot, 10.IV.2012, Deknuydt leg. (CFD); 1q, La Montagne du Vauclin, Le Vauclin, 22.IV.2012, Romé leg. (CDR); 1오 La Montagne du Vauclin par Ensfelder, Le Vauclin, 24.IV.2012, Delannoye leg. (CRD); 19, Maison du Moine, 26.VII.2012, Delannoye leg. (CRD); 1 nymph, La Montagne du Vauclin par Ensfelder, Le Vauclin, 11. II.2014, Delannoye leg. (CRD); 1오․ Forêt de l’Epinay, 26.II.2014, Romé leg. (CDR); 19 , Morne Bigot, Les Anses d’Arlet, 15.XII.2014, Ravat Ph. (CPR); 1ð̄, Morne Constant, Le Diamant, 10.X.2015, Touroult \& Poirier leg. (RCNM); $1 \widehat{\jmath}$, Morne Gentil, Les Anses d’Arlet, 13.X.2015, Touroult \& Poirier leg. (RCNM); 1 nymph, Rivière Rouge, Gros Morne, 26.IV.2016, Delannoye leg. (CRD); 1َ̧, Rivière Rouge, Malaise Trap, 2-9. XI.2017, Dumbardon-Martial leg. (CEDM); 1ð̄, Morne Sulpice, 24.XI.2017, Moulin \& Ramage leg. (RCNM); 1 nymph, Morne-Rouge, 3.IV.2019, Touroult leg. (RCNM); 1ðૈ, Le François, Morne Valentin, 28.IV.2019, Poirier \& Touroult leg. (RCNM); 1 , Rivière Pilote, Forêt de Lépinay, 22.XII.2019, Romé leg. (CDR); 1 q, Montagne du Vauclin, Vauclin, 21.IV.2020, Romé leg. (CDR); 1ㅇ, Les Anses d’Arlet, Morne Bigot, 12. VIII.2020, Ravat leg. (CPR); 1 nymph, Fort-de-France, Station thermale Absalon, 25 m Canopy in Dacryodes excelsa (Burseraceae), 7.X.2020, Moulin leg. (RCNM); 1 nymph, Le Marigot, 25.X.2020, Dubreuil leg. (CTD); 1 nymph, Fonds Saint-Denis, Morne Piquet, 15.XII.2020, Viscardi leg. (CMC).

Other data. Dominica. $3 \hat{\jmath}$, S. Chiltern, 5.XI-10. XII.1964, Spangler leg. (USNM) (Rivera \& Svenson 2020); 1ठ, Trois Pitons, 22.X.1964, Spangler leg. (USNM) (Rivera \& Svenson 2020); 2ð, $1.3 \mathrm{mi}$. E of Pont Casse, 12.V-27.IV.1964, Flint leg. (USNM) (Rivera \& Svenson 2020); Nymphs, Alford Estate, Chopin, 20.XII.1966, Bonfils \& Jean-Bart leg. (Bonfils 1967); $1 \delta^{\top}$, St. Paul Springfield State $2.5 \mathrm{~km}$ ENE Canefield $15^{\circ} 21^{\prime} \mathrm{N}$, $61^{\circ} 22^{\prime} \mathrm{W}, 450$ m, 11-18.VI.1991, Rawlins \& Thompson leg. (CM); 1ð̊, I.1999, Montgomery leg. (ANSP) (Rivera \& Svenson 2020).

Recent studied on morphology of many species of Thespidae (Rivera \& Svenson 2020) allowed transfer of Oligonyx insularis Bonfils, 1967 to the genus Thesprotiella. T. insularis is found in Basse-Terre in Guadeloupe, Marie-Galante, Martinique, Dominica (Bonfils 1967, 1969; Terra 1995; Ehrmann 2002; Otte \& Spearman 2005; Agudelo et al. 2007; Meurgey 2011; Patel et al. 2016; Meurgey \& Ramage 2020; Jourdan \& Moulin 2020; Otte et al. 2021). An Oligonyx female was also mentioned by McEDK (1953) on Trinidad and Tobago, but the specimen was not collected, and Greener \& Rutherford (2014) suggested that Kevan confused the specimen with Thesprotia filum.

Observations of $T$. insularis, irrespective of the island, have usually been made in sub humid or rain forests. FM, as part of a study on the Anolis Daudin, 1802 (Squamata, Dactyloidae) of Guadeloupe (Legreneur et al. 2017), was able to access the canopy, between 18 and $25 \mathrm{~m}$ high, where he observed many males of $T$. insularis. These observations appear to confirm the arboreal preference that Bonfils suggested in 1967 and 1969. The groundlevel observations of this species are likely to occur in individuals that have fallen from higher vegetation. NM has also observed a nymph at $25 \mathrm{~m}$ in the crown of a white gum tree (Dacryodes excelsa, Burserarceae), in the heights of the former spa of Absalon in Martinique.

T. insularis is a subendemic species of the Lesser Antilles: it is narrowly distributed in an area including part of the Lesser Antilles; with the status 'LC' in the Red Lists of the Fauna of Martinique (UICN Comité français, OFB, MNHN 2020) because it is widespread, and its habitats are not threatened now. (Jourdan \& Moulin 2020). Its status in Guadeloupe should be published at the end of 2021 by the IUCN.

Thesprotia caribea Rehn \& Hebard, 1938 (Figures 5a, b, 9h, i)

Thesprotia caribea Rehn \& Hebard 1938, p. 36.

Distribution. Antigua.

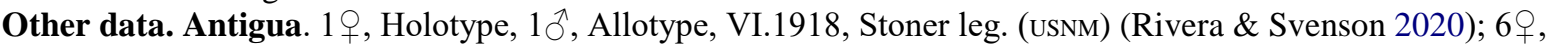
Paratypes, nymphs, hills and valleys, vicinity of English Harbor (village), VII.1918, Stoner leg. (Caudell 1922). 
Thesprotia caribea is found on Antigua (Rehn \& Hebard 1938; Terra 1995; Ehrmann 2002; Otte \& Spearman 2005; Agudelo et al. 2007; Patel et al. 2016; Otte et al. 2021). This species was later listed as occurring in “Antigua \& Barbuda” without further details (Rivera \& Svenson 2020). In the area considered in the present work, this species appears restricted to Antigua. Indeed, despite years of surveys, this species is lacking in records from Guadeloupe and Montserrat, respectively the largest and the closest islands around Antigua [Jourdan \& Moulin (2020) and this work for Guadeloupe, Ivie et al. (2008) for Montserrat].

\section{Family Liturgusidae}

Liturgusa dominica Svenson, 2014 (Figures 6a, b, 10a-d)

Liturgusa dominica Svenson 2014, p. 110.

Material examined. Marie-Galante. $1 \hat{\jmath}, 1$ ㅇ, Saint- Louis, Les Sources, 2.VIII.2007, Hugel leg. (CSH); $3 \hat{\partial}$, 1 , 1 nymph, Saint-Louis, Les Sources, 6.VIII.2011, Hugel leg. (CSH); 2 , , Saint-Louis, Les Sources, 7. VIII.2017, Hugel leg. (CSH); 2̂̉, Capesterre de Marie Galante, Les Balisiers, 6.VIII.2017, Hugel leg. (CSH); 1 nymph, Saint-Louis, Ravine Poirier, 29.V.2018, Leblond leg. (CFM); 4^̃, 3 \% , Saint-Louis, Les Sources, hand catching, 4-5.VI.2019, Moulin leg. (RCNM); $3 \hat{\jmath}, 1$, , Capesterre de Marie-Galante, Les Balisiers, hand catching, 5.VI.2019, Moulin leg. (RCNM).

Dominica. $1 \widehat{\partial}, 2$, 1 nymph, Spanny falls trail, 26. VII.2008, Hugel leg. (CSH, ABS). Other data. Dominica. 1 , , Paratype, Fond Figues, 16. III.1964, Bray leg. (USNM) (Rivera \& Svenson 2020); $1 \jmath^{\jmath}$, Holotype, 1 으,

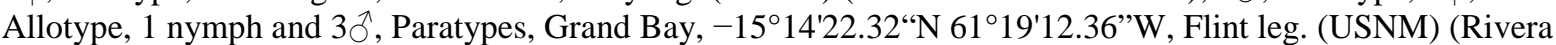
\& Svenson 2020); 1 nymph, Paratype, Clarke Hall, 22-31.X.1966, Gurney leg. (USNM) (Rivera \& Svenson 2020); 1 q, Paratype, B.W.I., La Haut Estate, 18.I.1979, Finnamore leg. (Lyman Museum) (Rivera \& Svenson 2020).

Liturgusa dominica was described after specimens collected in the 1960s on Dominica; this description was included in a review (Svenson 2014) of the Neotropical genus of bark-mimicking Mantises Liturgusa Saussure, 1869. The species was considered as endemic to Dominica since no other specimens were available.

In Marie-Galante, L. dominica occurs in the wettest areas of the sub humid forest around the Saint-Louis river. These are the most humid habitats of the island, which is a raised coral atoll of low elevation. These areas show some similarities with the locality where we observed $L$. dominica in Dominica. This species can be locally extremely abundant, with several specimens and oothecae present on almost all the trunks of more than $10 \mathrm{~cm}$ in diameter. Specimens can be observed both day and night.

L. dominica is neither present on the other islands of Guadeloupe (Guadeloupe, Terre-de-Haut and Terre-de- Bas of the Saintes island, the Desirade island), nor in St. Martin, in Martinique, in Saint Lucia, and in Saint- Vincent (Touroult \& Poirier 2012; Touroult et al. 2013, 2014b, 2015, 2016, 2017, 2018, 2019; Patel et al. 2016; Jourdan \& Moulin 2020). These islands have been surveyed extensively, as was Montserrat (Marske 2004), where the species is not recorded either.

L. dominica is a subendemic species of the Lesser Antilles. In Marie-Galante, its habitats are reduced (Joseph 2009; Ramade 2009) even if the populations are large in the known wooded ravines (Jourdan \& Moulin 2020). Its Red List status in Guadeloupe should be published at the end of 2021 by the IUCN.

\section{Family Acanthopidae}

Acontista multicolor Saussure, 1870

Acontista multicolor Saussure 1870, p. 229.

Distribution. Guadeloupe, Venezuela, Trinidad \& Tobago.

Material examined. Guadeloupe. 1 ㅇ Holotype, ‘Guadalupe’ (MNHN).

Despite intensive searching over the last decades, this species has not been found on Guadeloupe. Therefore, Acontista multicolor may be either currently very rare or extinct on Guadeloupe, or the historical mentions may correspond to an erroneous record. Indeed, Saussure (1870) mentions the name of the locality "Guadalupe" which is a very frequent toponym in America, and does not necessarily correspond to the island of Guadeloupe. This species is nevertheless present in Trinidad \& Tobago.

\section{Family Epaphroditidae}

Gonatista reticulata (Thunberg, 1815) (Figure 9e-g)

Mantis reticulata Thunberg 1815, p. 288.

Distribution. Saint Barthélemy, Dominican Republic, Puerto Rico.

Other data. Saint Barthélemy. $1 ð$ Holotype (Thunberg 1815).

Between the publication of Lombardo \& Perez-Gelabert (2004) and that of Agudelo et al. (2007), G. reticulata has been reported from the United States, which seems unlikely. Indeed, the Arizona data in Jantsch (1999) was included in 2007 without verification. Later, the distribution of this species is corrected, and its absence is confirmed from the United States (Svenson \& Rodrigues 2017).

Since its discovery by Thunberg (1815) from “Insula Barthelemi”, G. reticulata has never been seen in Saint Barthélemy.

Gonatista reticulata is probably present in Saint Barthélemy and well known in Dominican Republic, and Puerto Rico (Thunberg 1815; Saussure 1869; Caudell 1912; Giglio-Tos 1927; Beier 1935b; Terra 1995; Ehrmann 2002; 
Otte \& Spearman 2005; Agudelo et al. 2007; Patel et al. 2016; Otte et al. 2021; INaturalist 2021). The indicated presence in Cuba is an error due to repeated confusion. These specimens from Cuba are G. grisea.

Epaphrodita musarum (Palisot de Beauvois, 1805) (Figures 10e, 11d)

Mantis musarum Palisot de Beauvois 1805, p. 111.

Distribution. St. Lucia, Hispaniola.

Material examined. St. Lucia: $1 \delta$, Holotype of Epaphrodita undulata, 'Ste Lucia’ (MNHN).

The single male from St. Lucia was recently considered as a valid species (Roy 2005). Nevertheless, the morphological diversity of males of E. musarum males from Dominican Republic do not allow it to be distinguished from E. musarum. Three males from Dominican Republic kept in collection (RCNM) were compared to the male labeled from St. Lucia (Table 1).

We therefore restore the synonymy established by Giglio-Tos (1927): Epaphrodita undulata (Saussure, 1870), synonym of Epaphrodita musarum (Palisot de Beauvois, 1805).

\section{Family Mantidae}

Lobocneme lobipes Brunner \& Redtenbacher, 1892 (Figure 7, b)

Lobocneme lobipes Brunner \& Redtenbacher 1892, p. 206.

Distribution. St. Vincent, Grenada.

Other data. Grenada. 19, Mount Gay Estate, Granville (Windward side), - III.1893 (Brunner von Wattenwyl 1893).

St. Vincent. 1§, Holotype, south end of island, open swampy land near sea, beaten from bushes, 27.IX.1891, Smith leg. (BM) (Redtenbacher 1892); 1ㅇ, St. Vincent, 30. VIII.1902, Campbell leg. (Rehn 1905); 1ð,, Kingstown, 15. V.1937, Lombardo leg. (Ippolito \& Lombardo 2015).

Lobocneme lobipes is the only mantid of the Mantidae family present in Northern Lesser Antilles. The species is known in Grenada and St. Vincent (Redtenbacher 1892; Brunner von Wattenwyl 1893; Saussure \& Zehntner 1894; Kirby 1904; Rehn 1911; Giglio-Tos 1914, 1927; Marshall 1975; Terra 1995; Ehrmann 2002; Otte \& Spearman 2005; Agudelo et al. 2007; Ippolito \& Lombardo 2015; Patel \& Singh 2016; Otte et al. 2021). The male holotype of $L$. lobipes is illustrated in a recent publication by Ippolito \& Lombardo (2015). The female allotype from Grenada is illustrated in a publication by Brunner von Wattenwyl (1893).

FM reportedly observed L. lobipes specimens in rain forests of St. Vincent without collecting them. The genus Lobocneme is close to Parastagmatoptera. The latter is known to be mainly arboricolous in French Guyana (Roy 2019; Moulin \& Roy 2020). L. lobipes could plausibly occur in sub humid and rain forests.

Discussion and conclusion

We recorded nine species of Mantodea on Eastern Caribbean Islands. The islands have neither been connected in the past nor have they been connected to the continent. Southern Lesser Antilles emerged around 15-20 million years ago and the Northern Lesser Antilles emerged more recently, around 5-1.25 million years ago (Liebherr 1988; Wetterer et al. 2016; Crews \& Esposito 2020). Therefore, all terrestrial species occurring on these islands result from at least one event of colonization (Rosen 1975).

Four species are only found on these islands and should therefore be considered as endemic to this part of the Caribbean: Thesprotiella insularis, Thesprotia caribea, Liturgusa dominica and Lobocneme lobipes (Table 2). Three endemic species (T. insularis, L. dominica and L. lobipes) are not restricted to one single island but occur on nearby islands in the island arc. Interestingly, all of these endemic species display an arboricolous ecology and are all found in sub humid and rain forests; except T. caribea, which occurs in herbaceous areas.

The five other species occur on other islands of the Caribbean (Gonatista reticulata, Epaphrodita musarum) or are more widely distributed in Central America (Musonia surinama, Bantiella trinitatis, Acontista multicolor). A. multicolor, E. musarum, G. reticulata and B. trinitatis are arboricolous species, whereas $M$. surinama occurs in more herbaceous areas. These four species with wide distribution occur more in dry habitats compared to the habitat of the three endemic species (T. insularis, L. dominica and L. lobipes). While the distribution of endemic species is restricted to adjacent islands in the arc, non-endemic species are either known from one single island or from islands scattered on the archipelago. It is worth mentioning that the four non- endemic species known from one single island (Acontista multicolor, Epaphrodita musarum, Bantiella trinitatis and Gonatista reticulata) are only known from one single record and have not been collected again (Table 2). These scarce observations may either correspond to temporary settlements and/or to species occurring at very low density. It might also correspond to under sampling, particularly for T. caribea observed only in Antigua in 1918, E. musarum only in St. Lucia before 1870, like A. multicolor in Guadeloupe, and for G. reticulata the rediscovery of which is pending on tree trunks of St. Barthélemy.

One of the non-endemic species, Musonia surinama, is discontinuously distributed, occurring on the southernmost and a few northern-most islands (Table 2). Curiously, this species is lacking from large islands on the middle of the arc. Yet, some of these islands apparently display large rather dry herbaceous habitats suitable for the species, particularly the southern part of Martinique and the eastern part of Guadeloupe.

The discontinuous distribution of Musonia surinama in the arc may be explained by various colonization scenarios, involving distinct colonization waves, including one from the south as it has been shown for other 
groups (Martin Brown 1978; Woods 1990; Hedges 1996a, 1996b; Miller \& Miller 2001; Davies \& Birmingham 2002; Fontenla 2003). It may also involve more recent introduction in one area from the other one. It is possible that tropical storms carried timber with oothecae or even live specimens from island to island. A species of the genus Mantoida has been observed in captivity preferably depositing its oothecae in small holes directly in the wood. Such crevices occur in the wild, for example as exit holes of other insects, such as saproxylic beetles (Wieland \& Schütte 2011). The transfer of Mantodea oothecae via driftwood has previously been described (Werner 1909, 1915; Beier 1939; Ehrmann 2002; Harris 2007). Oothecae of bark mantises (L. dominica, G. reticulata) and arboricolous species ( $T$. insularis, $L$. lobipes) are usually attached to branches, on tree trunks (Svenson 2014; Rivera \& Svenson 2016; Brannoch et al. 2017) or deposited on the underside of leaves. Therefore, the dispersal of Mantodea via hurricanes and driftwood carrying oothecae or insects would provide a plausible explanation (Clark 1904). Wind dispersal of insects is a well-known phenomenon that may have played a role in some species such as B. trinitatis (Wiktelius 1981; Pasek 1988).

However, species dispersions can also be due to human trade, accidental introductions (Harris 2007). For example, $8 \%$ of the entomofauna in Guadeloupe is considered introduced by industry, agriculture, and trade (Meurgey \& Ramage 2020). The same goes for Barbados (Clark 1904; Nutting 1919).

Alternatively, to scenarios involving colonization events, this discontinuous distribution with areas of occurrence separated by large suitable habitats may result from local extinctions (Wunderle 2008). Indeed, the very habitat of Musonia surinama may have been in competition with past farming practices on these large islands, and insectivorous species such as mantids are likely to be directly and indirectly impacted by past use of pesticides (Krooss \& Schaefer 1998; Clermont- Dauphin et al. 2004; Cabidoche et al. 2009; Crabit et al. 2016).

Such speculative explanation linked to farming practices may also be consistent with the current lack of endemic mantid species on the herbaceous habitats of islands such as Guadeloupe and Martinique. On the other hand, agricultural practices can neither fully explain the lack of these species on central islands of the arc, since open forest and edges may be able to harbor graminicolous species too. Although a large proportion of these islands is protected (over 60\%), most of the protected areas are covered by forest (Gould et al. 2020).

Ongoing molecular studies may help to explain the current distribution of endemic and non-endemic mantids on these islands.

\section{Acknowledgements}

We would like to thank all of the contributors for their data and photographs that allowed this work to update the distributional knowledge of Mantodea from the northern Lesser Antilles (in alphabetic order): Julien Chalifour, Donatien Charles, Mathieu Coulis, Gwénael David, Francis Deknuydt, Régis Delannoye, Thomas Dubreuil, Eddy Dumbardon-Martial, Mathieu Jegu, Toni Jourdan (and work into the field), Gilles Leblond, Pierre- Damien Lucas, Eddy Poirier, Marc Pollet, Karl Questel, Philippe Ravat, Daniel Romé, Julien Touroult, Romain Tremblay, Guillaume Viscardi. We thank Philippe Grandcolas, Frédéric Legendre and Roger Roy for access to the Mantodea collections of MNHN; as well as the outstanding work of Mantodea Species File website managers. Sampling in the canopy in Martinique was made possible thanks to the association “Tout Là-Haut” represented by Matias Loubes. Field surveys were partly supported by the Muséum national d'Histoire naturelle, Paris and Parc National de la Guadeloupe (convention 2016-SJ416-16). We thank the National Parks and Forestry Services of Guadeloupe, Dominica, Martinique, St. Lucia and St. Vincent for giving access and allowing research in the protected areas. In Guadeloupe, we thank the Parc National de Guadeloupe, the DEAL Guadeloupe, and particularly Claudie Pavis and Anne-Marie Toussaint (INRAE, Guadeloupe) for access to INRAE campus in Guadeloupe, Hervé Magnin, Louis Redaud and Guy Van Laere. In Dominica, SH thanks the Dominica Forestry, Wildlife \& Parks Division, particularly James Arlington and Albert Gallion; SH also thanks the team of Archbold Tropical Research Center, Springfield Field Station Dominica, particularly Nancy Osler for assistance. In Martinique, SH and NM thanks the DEAL Martinique, particularly Julien Mailles, Stephan Lerider and Julie Gresser, and Parc Naturel Régional de la Martinique, particularly Bénédicte Chanteur. In Saint Lucia, SH thanks The Forestry Department and particularly Michael Bobb; SH thanks also Lorraine Royall and Melvin Smith for their kind help. In St. Vincent, SH thanks The Forestry Department and particularly Fitzgerald Providence; SH also thanks Mark de Silva for his precious advices. NM thanks Lena Baraud, Arzhvaël Jeusset and Florian Kirchner for the rigorous work of assessing insect species within the framework of the IUCN Red Lists in the French Antilles.

We thank Antoine Mantilleri (MNHN) and two anonymous reviewers who made valuable comments on earlier drafts of the manuscript.

ReferencesAgudelo AA, Lombardo F, Jantsch LJ. 2007. Checklist of the Neotropical mantids (Insecta, Dictyoptera, Mantodea). Biota Colombiana. 8(2):105-158.Beebe W, Crane J, Hughes-Schrader S. 1952. An Annotated List of the Mantids (Orthoptera, Mantoidea [sic]) of Trinidad, B. W.I. Zoologica: Scientific Contributions of the New York Zoological Society. 37(19):245-258.Beier M. 1939. Die geographische Verbreitung der Mantodeen. Internationaler 7. Kongress der Entomologie, Berlin. 1:5-15.

Beier M. 1935a. Mantodea. Family Mantidae: subfam. Thespinae. Genera Insectorum. 200:1-32.Beier M. 1935b. Mantodea. Family Mantidae: subfam. Mantinae. Genera Insectorum. 203:1-146.Bennet FD, Alam MM. 1985. An annotated checklist of the insects and allied terrestrial arthropods of barbados. St. Augustine (Trinadad): Caribbean Agricultural Research and Development Institute; p. VI + 81.Bonfils J. 1967. Contribution à l'étude des Orthoptéroides des Antilles. III. Une espèce nouvelle du genre Oligonyx Saussure: description et notes biologiques. [Dict.]. Bulletin de la Société entomologique de France. 72:244-247.Bonfils J. 1969. Catalogue raisonné des insectes des Antilles françaises. 2 Dictyoptera: « Blattaria » et « Mantida ». Annales de Zoologie Ecologie Animale. 1(2):107-120.Brannoch SK, Wieland F, Rivera J, Klass KD, Béthoux O, 
Svenson GJ. 2017. Manual of praying mantis morphology, nomenclature, and practices (Insecta, Mantodea). ZooKeys. 696:1-100. doi:10.3897/zookeys.696.12542Bruner L. 1906. Report on the Orthoptera of Trinidad, West Indies. Journal of the New York Entomological Society. 14 (3):135-165.Brunner von Wattenwyl K. 1893. On the Orthoptera of the Island of Grenada, West-Indies. Proceedings of the Zoological Society of London. 1893:599-611.Cabidoche YM, Achard R, Cattan P, Clermont-Dauphin C, Massat F, Sansoulet J. 2009. Long-term pollution by chlordecone of tropical volcanic soils in the French West Indies: a simple leaching model accounts for current residue. Environmental Pollution. 157(5):1697-1705. doi:10.1016/j. envpol.2008.12.015.Caudell AN. 1912. Notes on the mantid genus Gonatista Sauss. Psyche. 19:160162. Caudell AN. 1922. Report on Orthoptera and Dermaptera collected by the Barbados-Antigua Expedition from the University of lowa in 1918. lowa Studies in Natural History. 10:19-34.Chalumeau F, Touroult J. 2005. Les Longicornes des Petites Antilles (Coleoptera, Cerambycidae): taxonomie, Ethologie, Biogéographie. Sofia (Bulgaria): Pensoft Publishers; $p$. 241.Chopard L. 1912. Contribution à la faune des Orthoptères de la Guyane française. Annales de la Société entomologique de France. 80:315-350.Clark AH. 1904. Notes on the insects of Barbados, St. Vincent, The Grenadines, and Grenada. Psyche. 11:114-117.Clermont-Dauphin C, Cabidoche YM, Meynard JM. 2004. Effects of intensive monocropping of bananas on properties volcanic soils in the uplands of the French West Indies. Soil Use and Management. 20:1-9.Crabit A, Cattan P, Colin F, Voltz M. 2016. Soil and river contamination patterns of chlordecone in a tropical volcanic catchment in the French West Indies (Guadeloupe). Environmental Pollution. 212:615-626. doi:10.1016/j.envpol. 2016.02.055Crane J. 1952. A Comparative Study of Innate Defensive Behavior in Trinidad Mantids (Orthoptera, Mantoidea [sic]). Zoologica: Scientific Contributions of the New York Zoological Society. 37(20):259-293.Crews SC, Esposito LA. 2020. Towards a synthesis of the Caribbean biogeography of terrestrial arthropods. BMC Evolutionary Biology. 20:12. https://doi.org/10.1186/ s12862-0191576-zDavies N, Birmingham E. 2002. The historical biogeography of two Caribbean butterflies (Lepidoptera: Heliconiidae) as inferred from genetic variation at multiple loci. Evolution. 56(3):573-589.Ehrmann R. 2002. Mantodea gottesanbeterinnen der Welt. Münster: Natur und Tier Verlag; p. 519.Fontenla JL. 2003. Biogeography of Antillean butterflies (Lepidoptera: Rhopalocera): patterns of association among areas of endemism. Transactions of the American Entomological Society. 129:399-410. https://www.jstor.org/stable/25078822.Giglio-Tos E. 1914. Mantidae esotici. VII. Vatinae. Bolletino dei Musei di Zoologia ed Anatomia comparata della R. Università di Torino. 29(684):1-87.Giglio-Tos E. 1915. Mantidi esotici. Generi e especie nuove. Bulletino della Società Entomologica Italiana. 46:134-200.Giglio-Tos E. 1927. Das Tierreich. 50. Lfg. Orthoptera Mantidae. Berlin: Walter de Gruyter \& Co.; p. XL + 707.Gould WA, Castro-Prieto J, AlvarezBerríos L. 2020. Climate change and Biodiversity Conservation in the Caribbean Islands. Encyclodepia of the World's Biomes. 1:114-125. doi:10.1016/B978-0-12-409548-9.12091-3Greener MS, Deacon AE, Rutherford MG, Sookdeo K. 2014. First Records of Mantids (Insecta: Mantodea) on Huevos Island, Trinidad and Tobago. Living World, Journal of the Trinidad and Tobago Field Naturalists' Club. 56.Greener MS, Rutherford MG. 2014. An Updated List of the Mantodea of Trinidad and Tobago, with Three New Records for Trinidad. Living World, Journal of the Trinidad and Tobago Field Naturalists' Club. 3546. Harris AC. 2007. Living Statilia maculata Thunberg (Insecta: Mantodea: Mantidae) and other invertebrates, frequently imported into Dunedin on used cars. The Weta. 33:17-19. Hebard M. 1919. Studies in the Dermaptera and Orthoptera of Colombia. 1. Dermaptera and Orthopterous families Blattidae, Mantidae and Phasmidae. Transactions of the American Entomological Society. 45:87-179.Hebard M. 1921. Studies in the Dermaptera and Orthoptera of Colombia. 2. Dermaptera and Orthopterous families Blattidae, Mantidae and Phasmidae. Transactions of the American Entomological Society. 47(2):107-169. Hebard M. 1922. Studies in the Mantidae and Phasmidae of Panama (Orthoptera). Transactions of the American Entomological Society. 48:327-362. Hebard M. 1924. Studies in the Dermaptera and Orthoptera of Ecuador. Proceedings of the Academy of Natural Sciences of Philadelphia. 76:109-248. Hebard M. 1933. Studies in the Dermaptera and Orthoptera of Colombia. Transactions of the American Entomological Society. 59(2):103-105, 120-125. Hedges SB. 1996a. Historical biogeography of West Indian vertebrates. Annual Review of Ecology and Systematics. 27:163-196. Hedges SB. 1996b. The origin of West Indian amphibians and reptiles. In: Powell R and Henderson R W, editors. Contributions to West Indian herpetology: a tribute to Albert Schwartz. Ithaca (New York): Society for the Study of Amphibians and Reptiles; p. 95-128.INaturalist. Available from https://www.inaturalist.org. [January 2021]Ippolito S, Lombardo F. 2015. Taxonomic considerations on Lobocneme Rehn, 1911 and Paraoxyopsis Rehn, 1911 and a new synonymy (Insecta Mantodea: Stagmatopterinae). Revue Suisse de Zoologie. 122(2):201-206. doi:10.5281/zenodo.29996.

Ivie MA, Marske KA, Foley IA, Guerrero KA, Ivie LL. 2008. Invertebrates of the assessment of the Center Hills, Montserrat. Durrell Conservation Monograph no. 1. Jersey (Channel Islands): Durrell Wildlife Conservation Trust; p. 319.Jantsch LJ 1999. Estudos filogenéticos em Mantódeos americanos (Insecta: Pterygota: Mantodea). Ph.D. Thesis. Pontiticia Universidade Católitca do Rio Grande do Sul, Porto Alegre (Brasil).Joseph P. 2009. La végétation forestière des Petites Antilles. Paris: Karthala; p. 490.Jourdan T, Moulin N 2020. Amélioration des connaissances sur les Phasmatodea et les Mantodea de la Guadeloupe et ses dépendances. Rapport ASPER pour la DEAL Guadeloupe. 45 pp.Kirby WF. 1904. A Synonymic Catalogue of Orthoptera. (Forficulidae, Hemimeridae, Blattidae, Mantidae and Phasmidae). London: British Museum, Natural History. 1: I-X, 1-501 (207-316).Krooss S, Schaefer M. 1998. The effect of different farming systems on epigeic arthropods: a five-year study on the rove beetle fauna (Coleoptera: Staphylinidae) of winter wheat. Agriculture, Ecosystems \& Environment. 69:121-133.La Greca M. 1939. Mantidi della Guiana inglese raccolti dalla spedizione Beccari. Bollettino degli Istituti di Zoologia e Anatomia Comparata, Genova. 19(113):1-8.Legreneur P, Meurgey F, Thomas J. 2017. Distribution des Anolis dans la canopée de la forêt ombrophile en coeur du Parc National de la Guadeloupe et réseaux trophiques. Mission du 22/05/2017 au 04/ 06/2017. 47 p. Unpublished.Liebherr I. 1988. Zoogeography of Caribbean insects. Ithaca (NY): Cornell University Press; p. 298.Lombardo F, Perez-Gelabert DE. 2004. The mantids of Hispaniola, with the description of two species (Mantodea). Boletín de la Sociedad Entomológica Aragonesa. 34:35-48.Marshall JA. 1975. Catalogue of the primary types of Mantodea in the British Museum (Natural History). Bulletin of the British Museum (Natural History) Entomology. 31 (8):309-329.Marske KA. 2004. Effects of volcanic ash on the insect food of the 
Montserrat oriole Icterus oberi Lawrence 1880. Report of thesis. Bozeman (Montana): Montana State University; 189 pp.Martin Brown F. 1978. The origins of the West Indian butterfly fauna. In: Gill F B, editor. 1978. Zoogeography in the Caribbean. The 1975 Leidy Medal Symposium. Academy of Natural Sciences of Philadelphia, Vol. 13. Philadelphia (PA): Special Publication; p. 5-30.McEDK K. 1953. LXXXI. A preliminary list of the Mantodea of Trinidad, B.W.I. Annals and Magazine of Natural History. 6(71):809-816.Meurgey F 2011. Les Arthropodes continentaux de Guadeloupe: Synthèse bibliographique pour un état des lieux des connaissances. Rapport SHNLH pour le Parc National de Guadeloupe. 184 pp, non publié.Meurgey F. 2014. Liste préliminaire des abeilles de Guadeloupe (Petites Antilles) et leur relations avec la flore butinée (Hymenoptera: Apoidea:Megachilidae,Apidae). Annales de la Société entomologique de France (N.S.). 50(1):89-110. doi:10.1080/.00379271.934039.Meurgey F. 2016. Bee species and their associated flowers in the French West Indies (Guadeloupe, Les Saintes, La Désirade, Marie-Galante, St Barthélemy and Martinique) (Hymenoptera: Anthophila: Apoidea). Annales de la Société entomologique de France (N.S.). 52(4):209-232.

doi:10.1080/00379271.2016.1244490.Meurgey F, Dumbardon-Martial E. 2016. Les Abeilles de Martinique (Antilles françaises) et leurs relations avec la flore butinée (Hymenoptera: Apoidea: Megachilidae, Apidae). Annales de la Société entomologique de France (N.S.). 51 (4):346-360. doi:10.1080/00379271.2015.1131623.Meurgey F, Dumbardon-Martial E. 2019. New records of bees for the French West Indies (Hymenoptera, Apoidea, Anthophila). Bulletin de la Société entomologique de France. 124(1):11-18. doi:10.32475/bsef_2051.Meurgey F, Questel K. 2015. Liste préliminaire des Abeilles de Saint-Barthélemy (Antilles françaises) et leurs relations avec la flore butinée (Hymenoptera: Apoidea: Megachilidae, Apidae). Annales De La Société Entomologique De France (N. S.). 51(3):208-214.

doi:10.1080/00379271.2015.1061232.Meurgey F, Ramage T. 2020. Challenging the Wallacean shortfall: a total assessment of insect diversity on Guadeloupe (French West Indies), a checklist and bibliography. Insecta Mundi. 786:1-183.Miller JY, Miller D. 2001. The biogeography of the West Indian Butterflies (Lepidoptera): an application of a vicariance/dispersalist model. In: Woods C A and Sergile F E, editors. 2001. Biogeography of the West Indies. Patterns and Perspectives. Boca Raton: CRC Press; p. 127-156.Miskimen GW, Bond RM. 1970. The insect fauna of St. Croix, United States Virgin Islands. Scientific Survey of Porto Rico and the Virgin Islands. 13(1):1-114. New York Academy of Sciences.Mittermeier RA, Gil PR, Pilgrim J, Brooks T, Mittermeier CG, Da Fonseca GAB, Ford H, Seligmann-Smith PA. 2005. Hotspots Revisited: earth's biologically richest and most endangered terrestrial ecoregions. Washington (DC): Conservation International; p. 329.Moulin N. 2020. When Citizen Science highlights alien invasive species in France: the case of Indochina mantis, Hierodula patellifera (Insecta, Mantodea, Mantidae). Biodiversity Data Journal. 8:e46989. doi:10.3897/BDJ.8.e46989Moulin N, Roy R. 2020. Synthèse des connaissances des Mantodea de Guyane. Naturae. 2020(2):31-53. doi:10.5852/ naturae2020a2.Myers N, Mittermeier RA, Mittermeier CG, Monseca GAB, Kent J. 2000. Biodiversity hotspots for conservation priorities. Nature. 403:853-858.Nutting CC. 1919. Barbados-Antigua expedition; narrative and preliminary report of a zoological expedition from the University of Iowa to the Lesser Antilles under the auspices of the Graduate College. University of Iowa Studies in Natural History. 8(3):1-274.Otte D, Spearman L. 2005. Mantida species file. Catalog of the Mantids of the World. Association of the Insects Diversity; p. 489.Otte D, Spearman L, Stiewe MBD 2021, March . Mantodea Species File Online. Version 5.0/5.0. http://Mantodea.Spe ciesFile.org.Palisot De Beauvois. 1805. Orthoptéres. Insectes recueillis en Afrique et en Amérique, dans les Royaumea D’Oware et de Benin, a Saint-Domingue et dans les états-unis, Pendant les années 1786-1797. Paris. 13(60-62):109-111.Pasek JE. 1988. 30. Influence of wind and windbreaks on local dispersal of insects. Agriculture, Ecosystems \& Environment. 22-23:539-554. doi:10.1016/0167-8809 (88)90044-8Patel S, Singh G, Singh R. 2016. A checklist of global distribution of Liturgusidae and Thespidae (Mantodea:

Annales de la Société entomologique de France (N.S.) 21Dictyoptera). Journal of Entomology and Zoology Studies. 4(6):793-803.Patel S, Singh R. 2016. Updated Checklist and Distribution of Mantidae (Mantodea: Insecta) of the World. International Journal of Research Studies in Zoology. 2(4):17-54. doi:10.20431/2454-941X.0204003.Peck SB. 2009. Beetle species diversity in the Lesser Antilles islands: how many species are really there? Insecta Mundi. 78:1-5.Peck SB. 2010. The beetles of the island of St. Vincent, Lesser Antilles (Insecta: Coleoptera); diversity and distributions. Insecta Mundi. 144:177.Peck SB. 2011. The diversity and distributions of the beetles (Insecta: Coleoptera) of the northern Leeward Islands, Lesser Antilles (Anguilla, Antigua, Barbuda, Nevis, Saba, St. Barthélemy, St. Eustatius, St. Kitts, and St. Martin-St. Maarten. Insecta Mundi. 159:1-54.Peck SB. 2016. The beetles of the Lesser Antilles (Insecta, Coleoptera): diversity and distributions. Insecta Mundi. 460:1-360.Peck SB. 2006. The beetle fauna of Dominica, Lesser Antilles (Insecta: Coleoptera): Diversity and distribution. Insecta Mundi. 20:165-209.Pfäuti P, Hollier J. 2012. Additions to the catalogue of mantid type material deposited in the Muséum d'histoire naturelle de Genève (Insecta: Mantodea). Revue suisse de Zoologie. 119(3):261267.Pierre J, Lalanne-Cassou B. 2014. Les papillons de jour de la Martinique (Lepidoptera: Rhopalocera et Castniidae). Lépidoptères. 23(57):2-8.Quesnel V. 1967. Observations on the reproductive behaviour of the mantis Acontiothespis multicolor. Living World, Journal Trinidad and Tobago Field Naturalist's Club. 53-56. Ramade F. 2009. Impact de l'homme moderne sur les forêts tropicales. In: Joseph P, editor. 2009. Ecosystèmes forestiers des Caraïbes. Acte du colloque. Karthala: Conseil Général de la Martinique; p. 15-32.Redtenbacher J. 1892. In: brunner von Wattenwyl K. \& Redtenbacher J. On the Orthoptera of the Island of St. Vincent, West Indies. Proceedings of the Zoological Society of London. 15:196220.Rehn JAG. 1905. Notes on a small collection of Orthoptera from the lesser Antilles, with the description of a new species of Orphulella. Entomological News. 16:173-182.Rehn JAG. 1911. Orthoptera. Fam. Mantidae. Subfam. Vatinae. Genera Insectorum. Bruxelles. 119:1-28.Rehn JAG, Hebard M. 1938. New genera and species of West Indian Mantidae and Phasmidae - orthoptera. Transactions of the American Entomological Society. 64:33-39.Rivera J, Svenson GJ. 2016. The Neotropical « polymorphic earless praying mantises" - part I: molecular phylogeny and revised higher-level systematics (Insecta: Mantodea, Acanthopoidea). Systematic Entomology. 41:607-649. doi:10.1111/sysen.12178Rivera J, Svenson GJ. 2020. The Neotropical Polymorphic Earless Praying Mantises: a taxonomic review of the genera and checklist of species. Entomological Society of America. 232 pp.Rosen DE. 1975. A vicariance model of Caribbean biogeography. Systematic Zoology. 24(4):431-464.Roy R. 2005. Epaphrodita undulata (Saussure, 1870) bon species (Dict. Hymenopodidae). Bulletin 
de la Société entomologique de France. 110:57-58.Roy R. 2019. Les mantes (Dictyoptera, Mantodea) du massif du Mitaraka (Guyane). In: Touroult J, editor. "Our Planet Reviewed" 2015 large-scale biotic survey in Mitaraka. French Guiana: Zoosystema. 41 (5); p. 59-70. doi:10.5252/zoosystema2019v41a5Roy R, Cuche T. 2008. Catalogue du matériel type des mantes conservé au Muséum d'histoire naturelle de Genève (Insecta: Mantodea). Revue Suisse de Zoologie. 115:324.Saussure H. 1869. Essai d'un Système des Mantides. Mittheilungen der Schweizer, entomologischen Gesellschaft. 3:4973.Saussure H. 1870. Additions au Système des Mantides. Mittheilungen der Schweizer, entomologischen Gesellshaft. 3 (5):221-244.Saussure H. 1871. Mémoires pour servir à l'Histoire Naturelle du Mexique, des Antilles et États-Unis. IV. Synopsis des Mantides américains. Genève et Bâle. 1(4):5-186.Saussure H, Zehntner L. 1894. Fam. Mantidae. In Biologia Centrali-Americana. Insecta Orthoptera. Societas Entomologica. 1:123-197.Schwarz CJ, Roy R. 2019. The systematics of Mantodea revisited: an update classification incorporating multiple data sources (Insecta: Dictyoptera). Annales de la Société entomologique de France (N.S.). 55(2):101-196. doi:10.1080/ 00379271.2018.1556567.Stål C. 1877. Systema Mantodeorum. Essai d'une systématisation Nouvelle des Mantodées. Bihang Till K. Svenska Vet. Akad. Handlingar. 4(10):191.Svenson GJ. 2014. Revision of the Neotropical bark mantis genus Liturgusa Saussure, 1869 (Insecta, Mantodea, Liturgusini). ZooKeys. 390:1-214. doi:10.3897/zook eys.390.6661Svenson GJ, Rodrigues HM. 2017. A Cretaceous-aged Palaeotropical dispersal established an endemic lineage of Caribbean praying mantises. Proceedings of the Royal Society B. 284:20171280. doi:10.1098/rspb.2017.1280Terra PS. 1995. Revisão Sistemática dos Géneros de Louva- a-Deus da Região Neotropical. (Mantodea). Revista Brasileira de Entomologia. 39:13-94.Thunberg CP. 1815. Hemipterorum maxillosorum genera illustrate - plurimisque novis speciebus ditata ac descripta. Mémoires de l'Académie. 5:211-301. Touroult J, Deknuydt F, Poirier E, Romé D, Ravat P, Neild A. 2014a. Heraclides androgeus: un nouveau Papilionidae pour la faune de Martinique et confirmation de sa présence à Sainte-Lucie (Lepidoptera Papilionoidea). L'Entomologiste. 70(2):7377.Touroult J, Loïs G, Régnier C, Gigot G, Barnier F. 2020a. Le paradoxe de la connaissance naturaliste: des listes d'espèces qui s'allongent alors que la biodiversité décline. Revue Scientifique Bourgogne-Franche-Comté Nature. 31- 2020:258264.Touroult J, Poirier E 2012.Inventaire entomologique des ZNIEFF de Martinique. Mission 2011 pour le compte de la DEAL Martinique. Rapport de la Société entomologique Antilles-Guyane, n²012-1, 53 p., unpublished.Touroult J, Poirier E, Braud J, Deknuydt F, Dumbardon-Martial E, Moulin N, Ramage T, Romé D 2015. Inventaire entomologique des ZNIEFF de Martinique et de la Réserve de la Caravelle. Mission 2014 pour le compte de la DEAL Martinique. Rapport de la Société entomologique Antilles- Guyane, n²015-1, 66 p. + annexes, unpublished.Touroult J, Poirier E, Deknuydt F, Romé D 2013. Inventaire entomologique des ZNIEFF de Martinique. Mission 2012 pour le compte de la DEAL Martinique. Rapport de la Société entomologique Antilles-Guyane, $n^{\circ} 2013-3,54$ p., unpublished. Touroult J, Poirier E, Deknuydt $F$, Romé $D$, Ravat $P$, Lucas P-D 2014b. Inventaire entomologique des ZNIEFF de Martinique. Mission 2013 pour le compte de la DEAL Martinique. Rapport de la Société entomologique Antilles- Guyane, n²014-1, 46 p. + annexes, unpublished.Touroult J, Poirier E, Moulin N, Coulis M, Deknuydt F, Dumbardon-Martial E, Lupoli R, Ramage T, Romé D 2020b. Inventaire entomologique des ZNIEFF de Martinique. Campagne de terrain 2019. Rapport de la Société entomologique Antilles-Guyane, $n^{\circ} 2020-1,68$ p. + annexes, unpublished.Touroult J, Poirier E, Moulin N, Deknuydt F, Dumbardon- Martial E, Ramage T, Lucas P-D, Romé D. 2018. Inventaire entomologique des ZNIEFF de Martinique. Campagne de terrain 2017. Rapport de la Société entomologique Antilles- Guyane, n²018-1, 78 p. + annexes, unpublished.Touroult J, Poirier E, Moulin N, Deknuydt F, Dumbardon- Martial E, Ramage T, Romé D 2016. Inventaire entomologique des ZNIEFF de Martinique. Missions 2015-2016 pour le compte de la DEAL Martinique. Rapport de la Société entomologique Antilles-Guyane, $n^{\circ} 2016-1,68$ p. + annexes, unpublished.Touroult J, Poirier E, Moulin N, Deknuydt F, Dumbardon- Martial E, Ramage T, Romé D 2017. Inventaire entomologique des ZNIEFF de Martinique. Mission 2016 pour le compte de la DEAL Martinique. Rapport de la Société entomologique Antilles-Guyane, n²017-1, 74 p. + annexes, unpublished.Touroult J, Poirier E, Moulin N, Deknuydt F, Dumbardon- Martial E, Ramage T, Romé D 2019. Inventaire entomologique des ZNIEFF de Martinique. Campagne de terrain 2018. Rapport de la Société entomologique Antilles- Guyane, n²019-1, 72 p. + annexes, unpublished.UICN Comité français, OFB, MNHN. 2020. La Liste rouge des espèces menacées en France - chapitres de la faune de Martinique. Paris. Werner $F$. 1909. Bemerkungen über die geographische Verbreitung der Mantodeen (Fangheuschrecken). Verhandlungen der Kaiserlich-Königlichen Zoologisch-Botanischen Gesellschaft in Wien. 59:70-81.Werner F. 1915. Verschleppung von Fangheuschrecken (Mantodeen) durch den Schiffer-Verkehr. Zeitschrift für Wissenschftliche Insektenbiologie. 11:9899.Wetterer JK, Lubertazzi D, Rana JD, Wilson EO. 2016. Ants of Barbados (Hymenoptera, Formicidae). Breviora. 548 (1):134. doi:10.3099/brvo-548-00-1-34.1. Wieland F, Schütte K. 2011. Unrecognized museum specimen expands distribution of Mantoida (Insecta: Mantodea) into the central Caribbean. Entomologische Mitteilungen Aus Dem Zoologischen Museum Hamburg. 15(186):305-315. Wiktelius S. 1981. Wind dispersal of insects. Grana. 20:205-207.Woodruff RE, Beck BM, Skelley PE, Schotman CYL, Thomas MC. 1998. Checklist and Bibliography of the Insects of Grenada and the Grenadines. Gainesville (FL): Center for Systematic Entomology; p. 286. Woods CA. 1990. The fossil and recent land mammals of the West Indies: an analysis of the origin, evolution, and extinction of an insular fauna. Biogeographical Aspects of Insularity. Atti Dei Convegni Lincei 85:641-680.Wunderle JM. 2008. From the past to the globalized future for Caribbean birds. Journal of Caribbean Ornithology. 21 (2):69-79.Zagatti P, Lalanne-Cassou B, Le Duchat d'Aubigny J. 2021, January. Catalogue des Lépidoptères des Antilles Françaises. http://www7.inra.fr/papillon/ 